\title{
Business Feasibility Research in Opening Learning Centre at Balaraja based on SWOT and AHP Method
}

\section{Yunita}

Department of Information Technology, Swiss German University, Tangerang 15143, Indonesia

\section{Article Information}

Received: 10 December 2018 Accepted: 11 February 2019 Published: 25 April 2019

DOI: $10.33555 /$ jaict.v6i1.61

Corresponding Author:

Yunita

Email: yunita@student.sgu.ac.id

ISSN 2355-1771

\section{ABSTRACT}

Business feasibility research is needed before business development team decided to start the business. SWOT analysis is an important part of it, since it described Strength - Weaknesses - Opportunity - Threats. However, the result has no score, so its makes harder to consider each part in making decision. AHP (Analytic Hierarchy Process) is one of the methods in decision tool to scoring, AHP carry the quantitative analysis of the problem. The combine of SWOT and AHP in feasibility research provide more reliable accurate in decision making. The aim of this paper is to analyze the business feasibility in opening learning centre at Balaraja based on SWOT and AHP method.

Keywords: SWOT, AHP, Learning Centre Business Development 


\section{Introduction}

Nowadays education services are one of important needs in life after human basic needs. People start to consider their children education, to prepare their future winning competition in globalization. For creating the bright future, many school and learning centre offered method that believed develop children potential. In big city where education growth fast, we can easily find school and learning centre in international standard.

In business development, the consideration of location, market analysis become crucial in feasibility analysis before the business is started. According to the blue ocean strategy by W. Chan Kim and Renee Mauborgne, "organizations must find a marketplace that free from competitors". So rather than fighting against each other for share of the marketplace, new location that has potential market becomes important. Balaraja is one of city in Banten province of Indonesia, an urban city for support Jakarta as the capital city where the government has planned to develop Kota Tangerang as a smart city. Balaraja is chosen as a potential city for business development to open a learning centre with international standard. Major parts of business feasibility are opportunity identification and risk identification. SWOT method is one of the effective tools to do the business feasibility since it described Strength Weakness in internal factors and Opportunity - Threat from external factors. SWOT analysis is a qualitative analysis and combined with AHP analysis, the qualitative analysis can be measured in some degrees.

\section{Methodology}

\subsection{SWOT Method}

SWOT are stands for Strengths, Weaknesses, Opportunities and Threats. It is an effective analytical framework for feasibility study which identifies the strengths, weaknesses, opportunities and threats factors before business is launched. The method was created in the 1960s by Edmund P. Learned, C. Roland Christensen, Kenneth Andrews and William D. Book in their book "Business Policy, Text and Cases". SWOT analysis is described in SWOT matrix as shown in Table 1:

Table 1. SWOT Matrix

\begin{tabular}{|c|c|}
\hline STRENGTHS & OPPORTUNITIES \\
\hline WEAKNESSES & THREATS \\
\hline
\end{tabular}

\section{2. $A H P$}

AHP is a method that introduced by Dr. Thomas L. Saaty in early of 1970. In multi criteria decision making. AHP decompose problem into a hierarchy which divide goals and criteria or alternative. The subjective evaluation is valued in number and processed to rank each alternative in a numerical scale.

\subsection{SWOT-AHP Method}

SWOT method focus on qualitative analysis that describe Strength - Weakness Opportunity - Threat. From the analysis described in SWOT, it is difficult to take a decision 
since all item analyzed have no score. With AHP method, the decision can be considered by comparing the weight of SWOT analysis.

The proposed method is applied in four steps [1]:

1. Describe internal factor in Strength - Weaknesses and external factor in Opportunity Threat analysis in SWOT matrix.

2. From the matrix, applies the pair wise comparisons to get the weight of each SWOT items. In this step, invite several experts pair wisely compare each element and give the scores depend on the 1 9 scaling method as shown in Table 2

Table 2. Score meaning in the 1 9 scaling method

\begin{tabular}{ll}
\hline \multicolumn{1}{c}{ Score } & \multicolumn{1}{c}{ Meaning } \\
\hline 1 & Almost the same in importance \\
3 & Few differences in importance \\
5 & Strong difference in importance \\
7 & Very different in importance \\
9 & Extreme difference in importance \\
$2,4,6,8$ & Transition stage \\
\hline
\end{tabular}

From the pair wise, get the comparative matrix,

$$
\mathrm{C}=\left(\begin{array}{ccc}
\mathrm{c} 11 & \ldots & \mathrm{c} 1 \mathrm{n} \\
\ldots & \ldots & \ldots \\
\mathrm{cn} 1 & \ldots & \ldots
\end{array}\right)
$$

$c_{i j}$ means the importance of $C_{i}$ relative to $C_{j}$.

Calculate the weight, and the Consistency Index (CI), Consistency Ratio (CR), Random Index (RI), and then go to consistency test.

$$
\mathrm{CI}=\frac{\lambda_{\max }-\mathrm{n}}{\mathrm{n}-1}
$$

$\lambda_{\max }$ is the largest eigen value of the comparative matrix., $\mathrm{n}$ is number of dimension of the comparative matrix. RI value is obtained from the Table 3.

Table 3. Random Index (RI)

\begin{tabular}{|c|c|c|c|c|c|c|c|c|c|}
\hline $\mathrm{N}$ & 1 & 2 & 3 & 4 & 5 & 6 & 7 & 8 & 9 \\
\hline $\mathrm{RI}(\mathrm{N})$ & 0.00 & 0.00 & 0.58 & 0.90 & 1.12 & 1.24 & 1.32 & 1.41 & 1.45 \\
\hline
\end{tabular}

$$
\mathrm{CR}=\frac{\mathrm{CI}}{\mathrm{RI}}
$$


If $\mathrm{CR}<0.1$, the consistency is passed; but if not then built another comparative matrix until CR $<0.1$

3. Pair wisely compares each group, go to consistency tests. Repeating step 2 with the same formula.

4. Get comprehensive understanding of the internal and external environment by calculating the results, and make the corresponding strategy.

\section{Case study: Learning Centre Opening in Balaraja}

The methods are used to measure feasibility business in opening learning centre in Balaraja. The SWOT table is described in Table 4:

Table 4. SWOT Analysis Matrix

\begin{tabular}{|l|l|}
\hline Strengths & Opportunities \\
S1 : Simple learning method & O1 : There are many students in Balaraja \\
S2 : Power of international brand & O2 : Few of learning centre in Balaraja \\
S3 : Comfortable starting point & O3 : People loves to try something new \\
\hline Weaknesses & Threats \\
W1 : Subject options: Math and English & T1 : Consistency of parents and children \\
W2 : No instant method & following the program \\
W3 : Adding homework after school & T3: Another learning centre that provide \\
& all subjects
\end{tabular}

In each group, with the business development member team, scoring the 1- 9 scaling method, then count the weight.

First step compares the SWOT factors by scoring Strength (S), Weakness (W), Opportunities (O) and Threat (T). The highest weight score is Opportunities with score 0.508 shown in Table 5 .

Table 5. Pair wise comparison of SWOT factors

\begin{tabular}{llllll}
\hline SWOT Groups & S & W & O & T & Weight \\
\hline Strengths (S) & 1 & 3 & $1 / 3$ & 1 & 0.193 \\
Weaknesses (W) & $1 / 3$ & 1 & $1 / 5$ & $1 / 5$ & 0.070 \\
Opportunities (O) & 3 & 5 & 1 & 3 & 0.508 \\
Threat (T) & 1 & 5 & $1 / 3$ & 1 & 0.229 \\
\hline $\mathrm{CR}=0.043$ & & & & & \\
\hline
\end{tabular}

Next, we compare each element of SWOT factors that described in Table 4 by scoring and calculate the weight. The strength highest score is power of international brand with score 0.556, shown in Table 6. People in urban city have tendency like the branded things.

Table 6. Comparison Matrix of Strengths Group

\begin{tabular}{lllll}
\hline $\mathbf{S}$ & S1 & S2 & S3 & Weight \\
\hline S1. Simple learning method & 1 & $1 / 5$ & $1 / 5$ & 0.090 \\
S2. Power of international brand & 5 & 1 & 2 & 0.556 \\
S3. Comfortable starting point & 5 & $1 / 2$ & 1 & 0.354 \\
\hline CR $=0.047$ & & & \\
\hline
\end{tabular}


Next factor to compare is Weaknesses, shown in Table 7. The highest score of weaknesses is homework added after school with score 0.261. People love instant method rather than discipline learning process.

Table 7. Comparison Matrix of Weaknesses Group

\begin{tabular}{lllll}
\hline Weaknesses & W1 & W2 & W3 & Weight \\
\hline W1 : Subject options: Math and English & 1 & 5 & 3 & 0.633 \\
W2 : No instant method & $1 / 5$ & 1 & $1 / 3$ & 0.106 \\
W3: Adding homework after school & $1 / 3$ & 3 & 1 & 0.261 \\
\hline CR= 0.033 &
\end{tabular}

The third factor compared is Opportunities, shown in Table 8. The highest score for this factor is people love to try something new with score 0.591 . Balaraja is urban city with urban people who love to try something new that become great opportunity for business.

Table 8. Comparison Matrix of Opportunities Group

\begin{tabular}{lllll}
\hline Opportunities & O1 & O2 & O3 & Weight \\
\hline O1 : There are many students in Balaraja & 1 & 5 & $1 / 2$ & 0.334 \\
O2 : Few of learning centre in Balaraja & $1 / 5$ & 1 & $1 / 7$ & 0.075 \\
O3 : People loves to try something new & 2 & 7 & 1 & 0.591 \\
\hline CR $=0.012$ &
\end{tabular}

The last factor compared is Threat shown in Table 9. The highest factor score for Threat is school extracurricular program with score 0.525. Today many school with international standard offered many activities for extracurricular that makes students already tired with full activity from morning to afternoon.

Table 9. Comparison Matrix of Threat Group

\begin{tabular}{|c|c|c|c|c|}
\hline Threats & T1 & T2 & T3 & Weight \\
\hline $\begin{array}{l}\mathrm{T} 1 \text { : Consistency of parents and children } \\
\text { following the program }\end{array}$ & 1 & $1 / 2$ & 3 & 0.334 \\
\hline $\mathrm{T} 2$ : School extracurricular program & $1 / 3$ & 1 & 3 & 0.525 \\
\hline $\begin{array}{l}\mathrm{T} 3 \text { : Another learning centre that provide } \\
\text { all subjects }\end{array}$ & $1 / 3$ & $1 / 3$ & 1 & 0.141 \\
\hline $\mathrm{CR}=0.046$ & & & & \\
\hline
\end{tabular}


Finally, we compare all factors and the element to consider whether the learning center fit to open in Balaraja.

Table 10. Weight

\begin{tabular}{|c|c|c|c|c|}
\hline SWOT & $\begin{array}{c}\text { Weight } \\
\text { of each } \\
\text { group }\end{array}$ & Elements & $\begin{array}{c}\text { Weight } \\
\text { of each } \\
\text { element }\end{array}$ & $\begin{array}{c}\text { Total } \\
\text { weight }\end{array}$ \\
\hline \multirow[t]{3}{*}{ Strength } & \multirow[t]{3}{*}{0.193} & S1 : Simple learning method & 0.090 & 0.017 \\
\hline & & S2 : Power of brand internationally & 0.556 & 0.749 \\
\hline & & S3 : Comfortable starting point & 0.354 & 0.068 \\
\hline \multirow[t]{3}{*}{ Weaknesses } & \multirow[t]{3}{*}{0.070} & W1 : Subject options: Math and English & 0.633 & 0.044 \\
\hline & & W2 : No instant method & 0.106 & 0.007 \\
\hline & & W3 : Adding homework after school & 0.261 & 0.018 \\
\hline \multirow[t]{4}{*}{ Opportunities } & \multirow[t]{4}{*}{0.508} & $\mathrm{O} 1$ : There are many students in & 0.334 & 0.170 \\
\hline & & Balaraja & & \\
\hline & & $\mathrm{O} 2$ : Few of learning centre in Balaraja & 0.075 & 0.038 \\
\hline & & O3 : People loves to try something new & 0.591 & 0.3 \\
\hline \multirow[t]{3}{*}{ Threats } & \multirow[t]{3}{*}{0.229} & $\begin{array}{l}\mathrm{T} 1 \text { : Consistency of parents and children } \\
\text { following the program }\end{array}$ & 0.334 & 0.076 \\
\hline & & T2 : School extracurricular program & 0.525 & 0.120 \\
\hline & & $\begin{array}{l}\text { T3 : Another learning centre that provide } \\
\text { all subjects }\end{array}$ & 0.141 & 0.032 \\
\hline
\end{tabular}

The AHP analysis result show the ranking weight of SWOT analysis in Strength 19.3\%, Weaknesses $7 \%$, Opportunity 50.3\% and Threat 22.9\%. It describes Balaraja have big opportunity for opening learning centre by business development team.

\section{Conclusion}

In this paper, the findings show weight of each SWOT group priority: Strengths (group weight 19.3\%), Opportunities (50.3\%), Weaknesses (7.3\%) and Threats (22.9\%). As we can see the highest score of weight is in opportunity where Balaraja have many students who loves to try something new that supported by power of international brand as the strength. The calculation of weight of SWOT element made decision support easier since we can rank the weight of SWOT elements.

\section{References}

Görener, A., Toker, K. and Uluçay, K., 2012. Application of combined SWOT and AHP: a case study for a manufacturing firm. Procedia-Social and Behavioral Sciences, 58, pp.1525-1534.

Gu, L., Wang, C. and Liu, J., 2013. SWOT Analysis for planning development of Agricultural Logistics in Anhui Povince. Information Technology Journal,12(23), p.7336.

Kim, W.C. and Mauborgne, R., 2005. Blue ocean strategy: from theory to practice. California Management Review, 47(3), pp.105-121. 
Lumaksono, H., 2014. Implementation of SWOT-FAHP Method To Determine The Best Strategy on Development of Traditional Shipyard in Sumenep.Academic Research International, 5(5), p.56.

Pakseresht, A. and Asgari, G., 2012. Determining the critical success factors in construction projects: AHP approach. Interdisciplinary Journal of Contemporary Research In Business, 4(8), pp.1-11.

Sener, H.Y., 2014. Determining New Markets Using Analytic Hierarchy Process: Case Study in Güral Porcelain. International Journal of Marketing Studies, 6(5), p.149.

Yu, B., 2014. A Novel Method of Real Estate Development Project's Feasibility Research Based on SWOT Method and Analytic Hierarchy Process. International Journal of Business and Social Science, 5(5). 